\title{
Alkalibacterium subtropicum sp. nov., a slightly halophilic and alkaliphilic marine lactic acid bacterium isolated from decaying marine algae
}

Correspondence

Morio Ishikawa

m1ishika@nodai.ac.jp

\author{
Morio Ishikawa, Kazuyuki Nakajima, Shihomi Ishizaki, Kayo Kodama, \\ Akiko Okamoto-Kainuma, Yukimichi Koizumi, Yasushi Yamamoto \\ and Kazuhide Yamasato
}

Department of Fermentation Science, Faculty of Applied Bio-Science, Tokyo University of
Agriculture, 1-1 Sakuragaoka 1-chome, Setagaya-ku, Tokyo 156-8502, Japan

Two novel strains of marine lactic acid bacteria, isolated from decaying marine algae collected from a subtropical area of Japan, are described. The isolates, designated $024-2^{\top}$ and $025-2$, were Gram-positive, non-sporulating and non-motile. They lacked catalase and quinones. Under anaerobic cultivation conditions, lactate was produced from glucose with the production of formate, acetate and ethanol in a molar ratio of approximately $2: 1: 1$. Under aerobic cultivation conditions, acetate and lactate were produced from carbohydrates and related compounds. The isolates were slightly halophilic, highly halotolerant and alkaliphilic. They were able to grow in $0-17.0 \%(w / v) ~ N a C l$, with optimum growth of strains $024-2^{\top}$ and $025-2$ at $1.0-3.0$ and 1.0-2.0\% (w/v) NaCl, respectively. Growth of strain $\mathrm{O} 24-2^{\top}$ was observed at $\mathrm{pH} 7.5-9.5$, with optimum growth at $\mathrm{pH}$ 8.0-8.5. Comparative 16S rRNA gene sequence analysis revealed that the isolates occupied a phylogenetic position within the genus Alkalibacterium, showing highest similarity (99.6\%) to Alkalibacterium putridalgicola T129-2-1 ${ }^{\top}$. Although sequence similarity was high, the DNA-DNA relatedness value between strain $024-2^{\top}$ and $A$. putridalgicola $\mathrm{T} 129-2-1^{\top}$ was $27 \%$, indicating that they are members of distinct species. The DNA G + C contents of O24$2^{\top}$ and $025-2$ were 43.7 and 44.4 mol\%, respectively, and DNA-DNA relatedness between the isolates was $89 \%$. The cell-wall peptidoglycan was type A4 $\beta$, Orn-D-Asp. The major cellular fatty acid components were $\mathrm{C}_{14: 0}, \mathrm{C}_{16: 0}$ and $\mathrm{C}_{16: 1} \omega 9 \mathrm{c}$. Based on phenotypic characteristics and genetic distinctiveness, the isolates were classified as representatives of a novel species within the genus Alkalibacterium, for which the name Alkalibacterium subtropicum sp. nov. is proposed; the type strain is $024-2^{\top}\left(=\mathrm{DSM} 23664^{\top}=\right.$ NBRC $\left.107172^{\top}\right)$.
The genus Alkalibacterium was proposed by Ntougias \& Russell (2001) with Alkalibacterium olivapovliticus, isolated from the wash water of edible olives, as the type species. Subsequently, Alkalibacterium psychrotolerans (Yumoto et al., 2004), Alkalibacterium iburiense (Nakajima et al., 2005) and Alkalibacterium indicireducens (Yumoto et al., 2008) were isolated from polygonum indigo fermentation liquor. Recently, four novel species of the genus Alkalibacterium isolated from marine organisms and salted foods were proposed: Alkalibacterium thalassium, Alkalibacterium pelagium, Alkalibacterium putridalgicola and Alkalibacterium kapii (Ishikawa et al., 2009). All species of the genus Alkalibacterium possess halophilic and alkaliphilic

The GenBank/EMBL/DDBJ accession numbers for the 16S rRNA gene sequences of strains $024-2^{\top}$ and $025-2$ are AB555562 and AB555563, respectively.

Two supplementary figures and three supplementary tables are available with the online version of this paper. properties and produce lactic acid as the main product of glucose fermentation.

Several species of slightly halophilic and alkaliphilic lactic acid bacteria have been isolated from decaying marine organisms. For these bacteria, members of the genera Marinilactibacillus (Ishikawa et al., 2003) and Halolactibacillus (Ishikawa et al., 2005), and four species of the genus Alkalibacterium (Ishikawa et al., 2009), the term 'marine lactic acid bacteria' has been proposed on the basis of their marine habitat and preferable growth under the physicochemical conditions found in seawater [total salt concentration, 3.2-3.8\% (w/v); pH 8.2-8.3 (surface)]. During the course of further isolation experiments of lactic acid bacteria from marine environments, novel slightly halophilic and alkaliphilic lactic acid bacteria were isolated from decaying marine algae collected in a subtropical area of Japan. Here, taxonomic characterization of the isolates is described. 
The lactic acid bacteria were isolated from decaying algae that were collected from a foreshore site near the Oujima Islet $\left(26^{\circ} 07^{\prime} \mathrm{N} 127^{\circ} 40^{\prime} \mathrm{E}\right)$ in Okinawa Prefecture, a subtropical area of Japan, in September 1998.

The lactic acid bacteria isolates were obtained by successive enrichment and subsequent pour-plating following previously described procedures (Ishikawa et al., 2003). For isolation from samples, a $7 \% \mathrm{NaCl}$ glucose-yeast extractpeptone-fish extract (GYPF) isolation broth was used for enrichment culture and a $7 \% \mathrm{NaCl}$ GYPF isolation agar ( $1.3 \%$ agar) was used for pour-plating. The compositions of these media were as described previously (Ishikawa et al., 2003), except for $\mathrm{pH}$. The final $\mathrm{pH}$ was adjusted to 9.0 by supplementing the media with $6.1 \mathrm{~g} \mathrm{Na}_{2} \mathrm{CO}_{3} \mathrm{l}^{-1}$ and $8.9 \mathrm{~g} \mathrm{NaHCO}_{3} \mathrm{l}^{-1}$. The first enrichment culture was incubated anaerobically at $30{ }^{\circ} \mathrm{C}$ for 3 days. For the second enrichment culture, broth medium was inoculated from the first enrichment culture, the $\mathrm{pH}$ of which had decreased to $<7.0$, and incubated anaerobically at $30{ }^{\circ} \mathrm{C}$ for 2 days.

Two strains of lactic acid bacteria were isolated from different kinds of marine algae: strain $\mathrm{O} 24-2^{\mathrm{T}}$ was from Galaxaura sp. and strain O25-2 was isolated from Ectocarpus sp. A. olivapovliticus NCIMB $13710^{\mathrm{T}}$, A. psychrotolerans JCM $12281^{\mathrm{T}}$, A. iburiense JCM $12662^{\mathrm{T}}$, A. indicireducens JCM $14232^{\mathrm{T}}$, A. thalassium T117-1-2 ${ }^{\mathrm{T}}$, A. pelagium T143-1-1 ${ }^{\mathrm{T}}$, A. putridalgicola T129-2-1 ${ }^{\mathrm{T}}$, A. kapii T22-1-2 ${ }^{\mathrm{T}}$, Marinilactibacillus psychrotolerans $\mathrm{M} 13-2^{\mathrm{T}}$ and Marinilactibacillus piezotolerans JCM $12337^{\mathrm{T}}$ were used as reference strains. The isolates and reference strains were grown on $2.5 \% \mathrm{NaCl}$ GYPF agar (pH 9.0; $1.3 \%$ agar) or in $2.5 \% \mathrm{NaCl}$ GYPF broth ( $\mathrm{pH}$ 9.0) (Ishikawa et al., 2003) at $30{ }^{\circ} \mathrm{C}$ unless described otherwise. Anaerobic cultivation was conducted by using AnaeroPack-Keep (not $\mathrm{CO}_{2}-$ generated; Mitsubishi Gas Chemical) as described previously (Ishikawa et al., 2009).

The compositions of media used and methods for characterization of conventional phenotypic features, growth responses to $\mathrm{pH}$, salt concentration in the cultivation medium and temperature, analysis of fermentation products, chemotaxonomic analysis, DNA G $+\mathrm{C}$ content, phylogenetic analysis and DNA-DNA relatedness were as described by Ishikawa et al. (2002, 2003, 2005, 2009), except where outlined below.

Phylogenetic trees were constructed by using the neighbour-joining method as described previously (Ishikawa et al., 2003, 2005) and the maximum-parsimony method as implemented in the program MEGA version 4.0 (Tamura et al., 2007).

The two isolates exhibited similar phenotypic features. Cells were Gram-positive, rod-shaped and non-motile. Phase-contrast micrographs of cells of the isolates are shown in Supplementary Fig. S1 (available in IJSEM Online). The isolates did not produce spores or catalase. Cultural characteristics, cellular morphology, sensitivity to antibiotics and other conventional taxonomic features are given in the species description.

Both of the isolates required carbohydrates, sugar alcohols or related compounds for growth under aerobic as well as anaerobic conditions. While the $\mathrm{OD}_{660}$ of cultures grown aerobically in $2.5 \% \mathrm{NaCl}$ glucose-Casamino acids-yeast extract broth (Ishikawa et al., 2002) was 0.2 to 0.3 , the $\mathrm{OD}_{660}$ of cultures grown in the same medium without glucose was below 0.05. Similarly, growth was poor in $2.5 \% \mathrm{NaCl}$ GYPF broth in which the glucose concentration was reduced from $1 \%$ to $0.1 \%$ and no growth was observed when glucose was omitted from the broth.

The isolates were aerotolerant and slightly sensitive to air. When semi-solid $2.5 \% \mathrm{NaCl}$ GYPF medium $(0.15 \%$ agar $)$ in a test tube was inoculated with a small amount of broth culture, mixed and incubated statically, the colonies that developed were uniform in both density and size throughout the medium column (about $6 \mathrm{~cm}$ in height). When cultivated on an agar medium plate exposed to the atmosphere, growth was less vigorous compared with that on an agar plate incubated anaerobically.

Nearly complete 16S rRNA gene sequences of the isolates were compared with those of lactic acid bacteria and other related bacteria from public databases. The sequences of the two isolates were identical and exhibited highest similarity to the type strain of A. putridalgicola (99.6\%) (Table 1). The next highest similarity values were to the type strains of $A$. kapii $(98.0 \%)$, A. olivapovliticus $(97.9 \%)$, A. thalassium (97.8\%), A. indicireducens (97.6\%), A. pelagium (97.6\%), A. psychrotolerans (96.7\%), A. iburiense (96.0\%), M. piezotolerans (96.0\%) and M. psychrotolerans (95.8\%) (Table 1). The phylogenetic tree constructed by using the neighbour-joining method showed that the isolates belonged to a cluster with $A$. putridalgicola within the radiation of described species of the genus Alkalibacterium (Fig. 1). A similar relationship between the isolates and the species of Alkalibacterium and Marinilactibacillus was also obtained by using the maximum-parsimony algorithm (Supplementary Fig. S2, available in IJSEM Online).

The DNA G $+\mathrm{C}$ contents of strain $\mathrm{O} 24-2^{\mathrm{T}}$ and $\mathrm{O} 25-2$ were 43.7 and $44.4 \mathrm{~mol} \%$, respectively. DNA-DNA hybridization data showed that these two isolates constituted a single genomic species, sharing $89 \%$ DNA-DNA relatedness. No significant DNA-DNA relatedness $(27 \%)$ was obtained between strain $\mathrm{O} 24-2^{\mathrm{T}}$ and $A$. putridalgicola $\mathrm{T} 129-2-1^{\mathrm{T}}$, which was the closest phylogenetic relative to the isolates (Table 1). The DNA-DNA relatedness values of strain O24$2^{\mathrm{T}}$ to strains of other species of the genera Alkalibacterium and Marinilactibacillus were 5-12\%, which are low enough to indicate that they belong to distinct species (Table 1).

The fermentation profiles of carbohydrates, sugar alcohols and related carbon compounds of the isolates are given in the species description. The isolates utilized a fairly wide range of substrates. Both isolates utilized starch and gluconate without gas production. 
Table 1. Sequence similarities and DNA-DNA relatedness of the novel isolates and related taxa

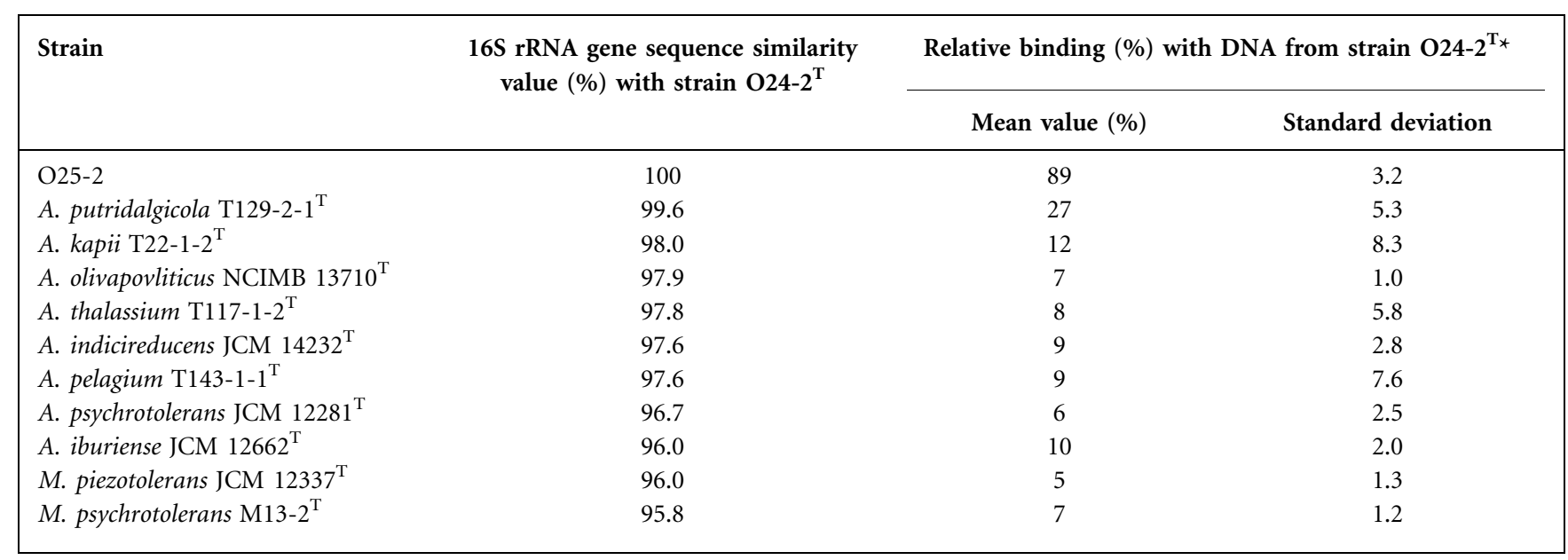

${ }^{\star}$ Values obtained from three repetitions, except for A. putridalgicola T129-2-1 ${ }^{\mathrm{T}}$, in which four repetitions were carried out.

The isolates were slightly halophilic (Kushner, 1978; Kushner \& Kamekura, 1988) and halotolerant. The optimum $\mathrm{NaCl}$ concentration for growth of strain $\mathrm{O} 24-2^{\mathrm{T}}$ was between 1.0 and $3.0 \%$ (1.0-2.0\% for strain $\mathrm{O} 25-2)$ when GYPF broth ( $\mathrm{pH} 8.5)$ was used and cells were cultivated statically at $30{ }^{\circ} \mathrm{C}$. The maximum specific growth rates $\left(\mu_{\max }\right)$ of strain $\mathrm{O} 24-2^{\mathrm{T}}$ were $0.29,0.30,0.38,0.42,0.41$, $0.41,0.26,0.26,0.22,0.14$ and $0.06 \mathrm{~h}^{-1}$ in $0.25,0.5,0.75,1.0$,
2.0, 3.0, 4.0, 5.0, 6.0, 7.0 and $8.0 \% \mathrm{NaCl}$, respectively. The isolates were able to grow in $0 \%$ (weak) to $17.0 \% \mathrm{NaCl}$. No growth was observed at $18.0 \% \mathrm{NaCl}$.

The isolates were alkaliphiles according to Jones et al. (1994): alkaliphiles are organisms that grow optimally at $\mathrm{pH}$ values greater than 8 . The optimum $\mathrm{pH}$ for growth was between 8.0 and 8.5 when $2.5 \% \mathrm{NaCl}$ GYPF broth was

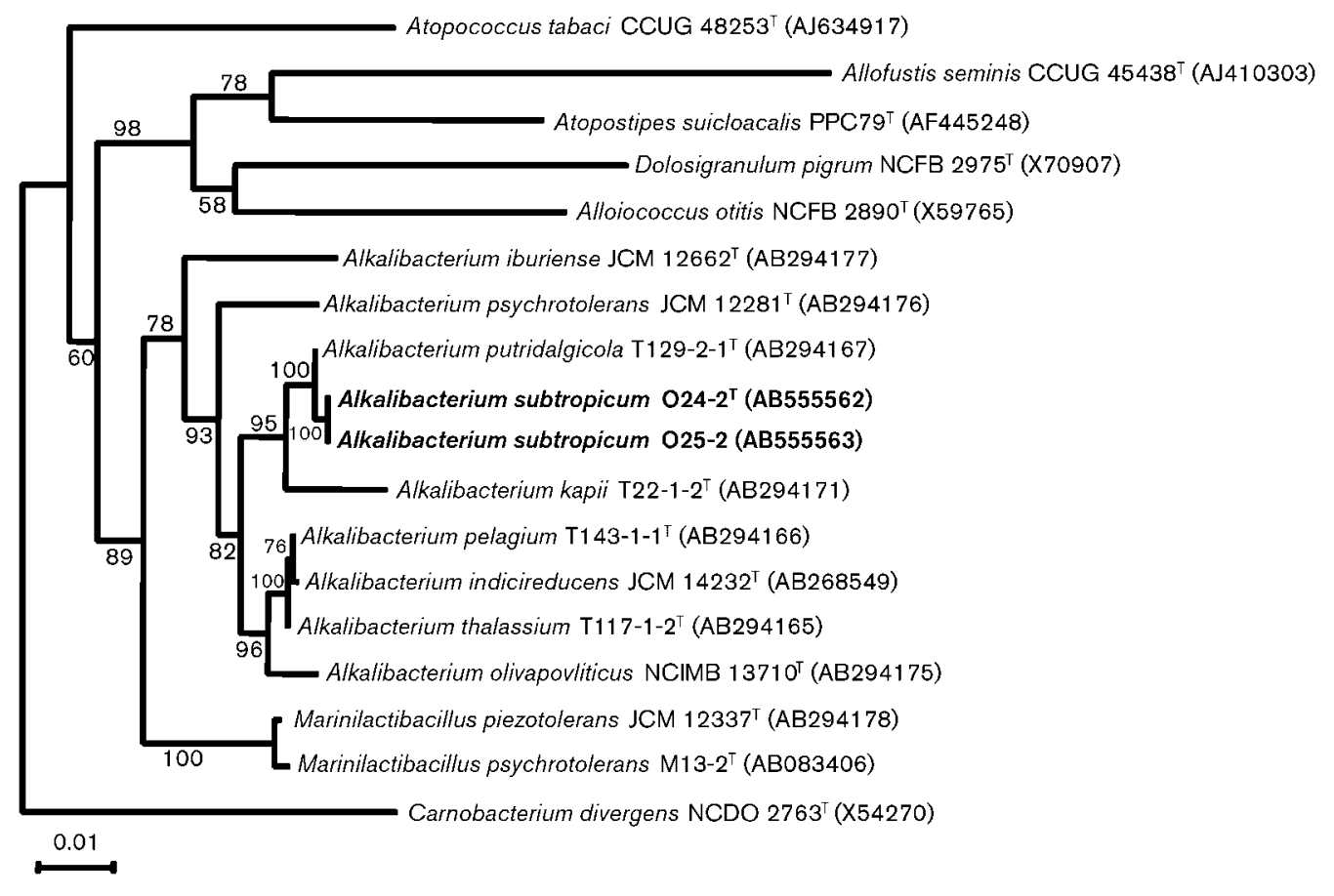

Fig. 1. Phylogenetic relationships between the novel isolates and related bacteria. The tree, constructed by the neighbourjoining method, is based on comparison of approximately $1400 \mathrm{nt}$. Bootstrap values, expressed as percentages of 1000 replications, are given at branch points; only values above $50 \%$ are shown. Bar, $0.01 K_{\text {nuc }}$. 
used and cells were cultivated statically at $30{ }^{\circ} \mathrm{C}$. The $\mu_{\max }$ values of strain $\mathrm{O} 24-2^{\mathrm{T}}$ were $0.18,0.60,0.54,0.37$ and $0.36 \mathrm{~h}^{-1}$ at $\mathrm{pH} 7.5,8.0,8.5,9.0$ and 9.5 , respectively. No growth was observed in media with initial $\mathrm{pH} \leqslant 7.0$ for strain $\mathrm{O} 24-2^{\mathrm{T}}$ ( $\leqslant 7.5$ for strain $\mathrm{O} 25-2$ ) or $\geqslant 10.0$.

Commonly occurring lactic acid bacteria are comparatively acid tolerant (their broth cultures attain a final $\mathrm{pH}$ of $<3.0$ ) and grow optimally at neutral to slightly acid $\mathrm{pH}$, such as 6.0. The isolates and members of the genus Alkalibacterium are not acid tolerant or neutralophilic, but they are alkaliphilic, as are M. psychrotolerans and Halolactibacillus species, which is a characteristic that is not present in common terrestrial lactic acid bacteria.

Among the genus Alkalibacterium, A. thalassium, A. pelagium, A. putridalgicola and A. kapii are marine inhabitants, isolated from marine organisms or salted foods produced from marine organisms, and possess halophilic and alkaliphilic properties consistent with those of seawater. The isolates reported here can be regarded as additional representatives of the marine lactic acid bacteria (Ishikawa et al., 2003, 2005, 2009) on the basis of habitat, physiological properties and lactic acid fermentation.

The optimum growth temperature of the isolates was 20 $30{ }^{\circ} \mathrm{C}$ when $2.5 \% \mathrm{NaCl}$ GYPF broth $(\mathrm{pH} 8.5)$ was used and cells were cultivated statically. The isolates grew at $15-40{ }^{\circ} \mathrm{C}$; no growth was observed at $\leqslant 10{ }^{\circ} \mathrm{C}$ or $\geqslant 42.5{ }^{\circ} \mathrm{C}$. The $\mu_{\max }$ values of strain $\mathrm{O} 24-2^{\mathrm{T}}$ were $0.24,0.28,0.28,0.28,0.18$ and $0.16 \mathrm{~h}^{-1}$ at $15,20,25,30,37$ and $40{ }^{\circ} \mathrm{C}$, respectively.

Fermentation products from glucose were analysed for anaerobic cultures grown in $2.5 \% \mathrm{NaCl}$ GYPF broth Lactate, formate, acetate and ethanol were produced without generation of gas; formate, acetate and ethanol were produced in a molar ratio of approximately $2: 1: 1$. The ratios of $\mathrm{L}(+)$ isomer to total lactate produced were 51 and $47 \%$ for strains $\mathrm{O} 24-2^{\mathrm{T}}$ and $\mathrm{O} 25-2$, respectively. The effect of the initial $\mathrm{pH}$ of the fermentation medium on the yield of lactate produced (mol glucose consumed) ${ }^{-1}$ was investigated by using media buffered with a series of Good's buffers (Ishikawa et al., 2002) for the isolates (Supplementary Table S1, available in IJSEM Online). To minimize the effect of $\mathrm{pH}$ changes that might occur during cultivation, product analysis was performed when cultures were at an early stage of growth (i.e. $\mathrm{OD}_{660}$ of approx. 0.2 ). As the initial acidity increased, the lactate yield relative to glucose consumed by strain $\mathrm{O} 24-2^{\mathrm{T}}$ increased, as observed in strains of the genera Alkalibacterium and Marinilactibacillus: $93 \%$ at $\mathrm{pH} 7.5$, $55 \%$ at $\mathrm{pH} 8.0$ and $26 \%$ at $\mathrm{pH}$ 9.0. Strain $\mathrm{O} 25-2$ produced similar amounts of lactic acid regardless of $\mathrm{pH}: 45 \%$ at $\mathrm{pH} 8.0$ and $38 \%$ at $\mathrm{pH} 9.0$. At all $\mathrm{pH}$ values, carbon recovery from consumed glucose was about $100 \%$ and the molar ratios of formate, acetate and ethanol were generally approximately 2:1:1 (Supplementary Table S2, available in IJSEM Online). Several homofermentative lactic acid bacteria, including members of the genera Alkalibacterium and Marinilactibacillus, have been reported to produce formate, acetate and ethanol, in addition to lactate, from glucose in a molar ratio of $2: 1: 1$. This phenomenon can be explained as follows. These homofermentative lactic acid bacteria possess pyruvate-associated enzymes, lactate dehydrogenase and pyruvate-formate lyase (Carlsson \& Griffith, 1974; Axelsson, 1993). Relative activities of these enzymes are affected by the $\mathrm{pH}$ of the fermentation medium or limited glucose concentration resulting in the generation of varying relative amounts of lactate and the other three products (Gunsalus \& Niven, 1942; Carlsson \& Griffith, 1974; Yamada \& Carlsson, 1975; Rhee \& Pack, 1980). As discussed for species of Marinilactibacillus (Ishikawa et al., 2003), Halolactibacillus (Ishikawa et al., 2005) and Alkalibacterium (Ishikawa et al., 2003, 2009), the isolates may have these two pyruvate pathways and, in strain $\mathrm{O} 24-2^{\mathrm{T}}$, the relative activities of the enzymes involved would be affected by the $\mathrm{pH}$ of the fermentation medium.

The isolates grew aerobically, although they lacked catalase and respiratory quinones. The end products from glucose under aerobic conditions were determined for strain O24$2^{\mathrm{T}}$ (Supplementary Table S2). Acetate and lactate were produced in molar ratios of 0.81 and 1.07 (per mol glucose consumed), respectively, but formate and ethanol were not generated. Carbon recovery was $81 \%$. If we assume that equimolar production of acetate and $\mathrm{CO}_{2}$ occurs, carbon recovery can be calculated as $95 \%$. Oxidative generation of equimolar amounts of acetate and $\mathrm{CO}_{2}$ from glucose that is not mediated by the respiratory chain has been reported for several other lactic acid bacteria (Fukui et al., 1988; Sakamoto \& Komagata, 1996; Liu et al., 2002). The isolates would have a relevant oxidative pathway of glucose as in the case of species of the genera Marinilactibacillus (Ishikawa et al., 2005), Halolactibacillus (Ishikawa et al., 2005) and Alkalibacterium (Ishikawa et al., 2009).

meso-Diaminopimelic acid was not associated with cell-wall peptidoglycans of the isolates as determined by TLC. Purified cell wall of strain $\mathrm{O} 24-2^{\mathrm{T}}$ contained aspartic acid, glutamic acid, alanine and ornithine in a molar ratio of $0.44: 1.0$ : $1.7: 1.0$. From this result, it was inferred that strain $\mathrm{O} 24-2^{\mathrm{T}}$ possessed peptidoglycan type A4 $\beta$, Orn-D-Asp, which is the cell-wall type of A. olivapovliticus (Ishikawa et al., 2003), A. thalassium (Ishikawa et al., 2009), A. pelagium (Ishikawa et al., 2009) and A. putridalgicola (Ishikawa et al., 2009).

The major cellular fatty acids of strain $\mathrm{O} 24-2^{\mathrm{T}}$ were straight-chain saturated and monounsaturated even-carbon-numbered types, as follows: $2.7 \% \mathrm{C}_{10: 0} ; 13.8 \% \mathrm{C}_{14: 0}$; $23.9 \% \mathrm{C}_{16: 0} ; 46.1 \% \mathrm{C}_{16: 1} \omega 9 c ; 0.6 \% \mathrm{i}-\mathrm{C}_{17: 1} \omega 9 c ; 1.1 \%$ $\mathrm{C}_{18: 0} ; 7.5 \% \mathrm{C}_{18: 1} \omega 9 c$, and $4.3 \%$ unknown fatty acid. The cellular fatty acid compositions of members of the Alkalibacterium are generally similar to each other (Supplementary Table S3, available in IJSEM Online). However, the proportion of $\mathrm{C}_{14: 0}$ in the cellular fatty acid composition of strain $\mathrm{O} 24-2^{\mathrm{T}}$ is relatively high compared with that found in other members of Alkalibacterium except for A. psychrotolerans (Supplementary Table S3).

Respiratory quinones were not present in strain $\mathrm{O} 24-2^{\mathrm{T}}$. 
Table 2. Differential characteristics of the novel isolates and phylogenetically related species

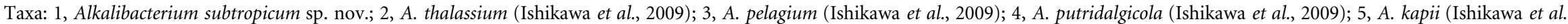

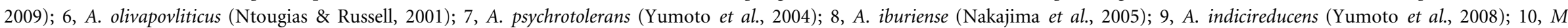

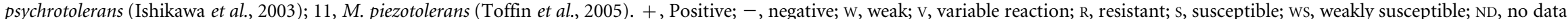

\begin{tabular}{|c|c|c|c|c|c|c|c|c|c|c|c|}
\hline Characteristic & 1 & 2 & 3 & 4 & 5 & 6 & 7 & 8 & 9 & 10 & 11 \\
\hline Motility & - & - & + & + & $\begin{array}{c}+ \\
\text { (most strains) }\end{array}$ & $+^{*}$ & + & + & + & + & - \\
\hline Flagella & - & - & Peritrichous & Peritrichous & Peritrichous & Peritrichous $^{*}$ & Peritrichous & Peritrichous & Peritrichous & Peritrichous & - \\
\hline Colony colour & Creamy white & Pale yellow & Pale yellow & Pale yellow & Creamy yellow & $\begin{array}{c}\text { Yellowish } \\
\text { white* }^{\star}\end{array}$ & Pale white & Pale white & Pale white & Pale yellow & Yellowish white ${ }^{\star} \dagger$ \\
\hline \multicolumn{12}{|l|}{$\mathrm{NaCl}(\%)$} \\
\hline Range & $0-17$ & $0-11$ & $0-17$ & 0 to $18-20$ & 0 to $19-21$ & $0-15$ & $0-17$ & 0 to $14-16$ & 0 to $14-15$ & 0 to $17-20.5$ & $0-12.0$ \\
\hline Optimum & 1.0 to $2.0-3.0$ & $1-2.5$ & $0.5-1.5$ & $2-4$ & $1.5-2.5$ & $3-5 \ddagger$ & $2-12$ & $3-13$ & $1-11$ & $2-3.75$ & $1.0-2.0$ \\
\hline \multicolumn{12}{|l|}{$\mathrm{pH}$} \\
\hline Range & $7.5-8.0$ to 9.5 & $7.0-11.0$ & $7.0-11.0$ & $6.0-6.5$ to 10 & $6.5-10.0$ & $8.5-10.8$ & $9.0-12.0$ & $9.0-12.0$ & $9.0-12.3$ & $6.0-10.0$ & $5.5-10.0$ \\
\hline Optimum & $8.0-8.5$ & 9.0 & $9.0-9.5$ & $8.0-9.0$ & $8.5-9.0$ & $9.0-10.2$ & $9.5-10.5$ & $9.5-10.5$ & $9.5-11.5$ & $8.5-9.0$ & $7.0-8.0$ \\
\hline \multicolumn{12}{|l|}{ Growth temperature $\left({ }^{\circ} \mathrm{C}\right)$ : } \\
\hline Range & $15-40$ & $10-42.5$ & $10-47.5$ & -1.8 to $40-45$ & $5-10$ to $40-42.5$ & 4 to $35-37$ & $5-45$ & $5-45$ & $15-40 / 18-37$ & -1.8 to $40-45$ & $4-50$ \\
\hline Optimum & $20-30$ & 37 & 37 & $37-40$ & $25-37$ & $27-32$ & 34 & $30-37$ & $20-30$ & $37-40$ & $37-40$ \\
\hline \multicolumn{12}{|l|}{ Fermentation of: } \\
\hline D-Xylose & + & - & + & + & - & - & + & $\mathrm{v}$ & - & + & + \\
\hline Sucrose & + & + & + & + & + & + & - & $\mathrm{v}$ & $\mathrm{W}$ & + & + \\
\hline Lactose & + & w & + & + & - & - & - & $+^{*}$ & ND & + or $\mathrm{w}$ & $-^{\star}$ \\
\hline Raffinose & + & w & $\mathrm{w}$ & + & - & - & - & - & - & V & $-{ }^{*}$ \\
\hline D-Salicin & + & + & + & + & - & $+^{*}$ & $+^{*}$ & $+^{*}$ & $\mathrm{ND}$ & $\mathrm{v}$ & $+^{*}$ \\
\hline Melibiose & + & - & - & - & - & - & - & - & - & $\mathrm{v}$ & ND \\
\hline Inulin & + & + & + & + or - & - & ND & - & $\mathrm{ND}$ & $\mathrm{ND}$ & $\mathrm{v}$ & $\mathrm{ND}$ \\
\hline \multicolumn{12}{|l|}{ Antibiotic sensitivity } \\
\hline Ampicillin (10 and $25 \mu \mathrm{g})$ & s & s & s & s & s & s & $s^{*}$ & s & s & $s^{*}$ & $s^{*}$ \\
\hline Chloramphenicol $(2 \mu \mathrm{g})$ & ws & $\mathrm{R}$ & $\mathrm{R}$ & $\mathrm{R}$ & $\mathrm{R}$ & s & $\mathrm{ws}^{*}$ & $\mathrm{R}$ & $\mathrm{R}$ & $\mathrm{R}^{*}$ & $\mathrm{R}^{*}$ \\
\hline Kanamycin $(2$ and $10 \mu \mathrm{g})$ & s & $\mathrm{R}$ & $\mathrm{R}$ & $\mathrm{R}$ & $\mathrm{R}$ & s & $\mathrm{R}$ & $\mathrm{R}$ & $\mathrm{R}$ & $R^{*}$ & $\mathrm{R}^{*}$ \\
\hline $\begin{array}{l}\text { Trimethoprim } \\
(10 \text { and } 25 \mu \mathrm{g})\end{array}$ & s & $\mathrm{R}$ & s & s & $\mathrm{R}$ & s & $s^{*}$ & $\mathrm{R}$ & $\mathrm{R}$ & $\mathrm{R}^{*}$ & $\mathrm{R}^{*}$ \\
\hline $\mathrm{NH}_{3}$ from L-arginine & - & - & - & + & - & $\mathrm{w}^{*}$ & $\mathrm{w}^{*}$ & $\mathrm{w}^{*}$ & $\mathrm{ND}$ & $\mathrm{w}$ & $\mathrm{w}^{*}$ \\
\hline Peptidoglycan type & $\begin{array}{c}\text { A4 } \beta \\
\text { Orn-D-Asp }\end{array}$ & $\begin{array}{c}\text { A4 } \beta, \\
\text { Orn-D-Asp }\end{array}$ & $\begin{array}{c}\text { A4 } \beta, \\
\text { Orn-D-Asp }\end{array}$ & $\begin{array}{c}\text { A4 } \beta, \\
\text { Orn-D-Asp }\end{array}$ & $\begin{array}{c}\text { A4 } \beta, \\
\text { Orn-D-Glu }\end{array}$ & $\begin{array}{c}\mathrm{A} 4 \beta \\
\text { Orn-D-Asp }\end{array}$ & $\begin{array}{l}\text { A4 } \alpha, \text { Lys } \\
\text { (Orn)-D-Asp }\end{array}$ & $\begin{array}{c}\text { A4 } \alpha, \\
\text { Lys-D-Asp }\end{array}$ & $\begin{array}{l}\text { A4 } \alpha, \text { Lys } \\
\text { (Orn)-D-Asp }\end{array}$ & $\begin{array}{c}\mathrm{A} 4 \beta \\
\text { Orn-D-Glu }\end{array}$ & ND \\
\hline Major cellular fatty acids & $\begin{array}{c}\mathrm{C}_{14: 0}, \mathrm{C}_{16: 0} \\
\mathrm{C}_{16: 1} \omega 9 c\end{array}$ & $\begin{array}{c}\mathrm{C}_{16: 0} \\
\mathrm{C}_{16: 1} \omega 9 c \\
\mathrm{C}_{18: 1} \omega 9 c\end{array}$ & $\begin{array}{c}\mathrm{C}_{16: 0} \\
\mathrm{C}_{16: 1} \omega 9 c \\
\mathrm{C}_{18: 1} \omega 9 c\end{array}$ & $\begin{array}{c}\mathrm{C}_{16: 0} \\
\mathrm{C}_{16: 1} \omega 9 c \\
\mathrm{C}_{18: 1} \omega 9 c\end{array}$ & $\begin{array}{c}\mathrm{C}_{16: 0} \\
\mathrm{C}_{16: 1} \omega 9 c \\
\mathrm{C}_{18: 1} \omega 9 c\end{array}$ & $\begin{array}{l}\mathrm{C}_{16: 0} \\
\mathrm{C}_{16: 1} \omega 9 c \\
\mathrm{C}_{18: 1} \omega 9 c\end{array}$ & $\begin{array}{c}\mathrm{C}_{14: 0}, \mathrm{C}_{16: 0} \\
\mathrm{C}_{16: 1} \omega 9 c \\
\mathrm{C}_{18: 1} \omega 9 c\end{array}$ & $\begin{array}{c}\mathrm{C}_{16: 0}, \\
\mathrm{C}_{16: 1} \omega 9 c \\
\mathrm{C}_{18: 1} \omega 9 c^{\star}\end{array}$ & $\begin{array}{c}\mathrm{C}_{16: 0} \\
\mathrm{C}_{16: 1} \omega 9 c \\
\mathrm{C}_{18: 1} \omega 9 c\end{array}$ & $\begin{array}{c}\mathrm{C}_{16: 0} \\
\mathrm{C}_{16: 1} \omega 9 c \\
\mathrm{C}_{18: 1} \omega 9 c^{\star}\end{array}$ & $\begin{array}{c}\mathrm{C}_{16: 0} \\
\mathrm{C}_{16: 1} \omega 9 c \\
\mathrm{C}_{18: 1} \omega 9 c^{\star}\end{array}$ \\
\hline DNA G $+C$ content $(\mathrm{mol} \%)$ & $43.7-44.4$ & 41.7 & 42.2 & $41.0-43.0$ & $38.4-39.4$ & $39.7 \pm 1.0$ & $42.6-43.2$ & $40.6\left(39.2^{\star}\right)$ & $47.0-47.8$ & $34.6-36.2$ & $42.0\left(36.6^{\star}\right)$ \\
\hline
\end{tabular}

${ }^{\star}$ Determined by Ishikawa et al. (2009).

$\dagger$ Cultivated anaerobically on $2.5 \% \mathrm{NaCl}$ GYPF agar.

$\ddagger$ Values for the type strain. 
The isolates were similar to members of the genus Alkalibacterium in the following characteristics: cellular morphology, various biochemical features, halophilic/halotolerant and alkaliphilic/alkalitolerant properties, products from glucose under aerobic and anaerobic conditions, and DNA G + C content. Although they shared important taxonomic features, the isolates and described species of the genus Alkalibacterium can be distinguished from each other by a combination of features, i.e. sugar fermentation patterns, sensitivity to antibiotics, growth responses to $\mathrm{NaCl}$ concentration, $\mathrm{pH}$ and temperature, the ability to produce ammonia from arginine, peptidoglycan type and DNA $\mathrm{G}+\mathrm{C}$ content (Table 2). The isolates could be distinguished from described species of Alkalibacterium by motility (except for A. thalassium) and antibiotic sensitivity (except for A. olivapovliticus), and from A. kapii, A. psychrotolerans, $A$. iburiense and $A$. indicireducens by peptidoglycan type (Table 2). Above all, the isolates could be distinguished from A. putridalgicola, which is the phylogenetically most closely related species, by motility, colony colour, temperature range for growth, sugar fermentation pattern, sensitivity to antibiotics, production of ammonia from L-arginine and major cellular fatty acids (Table 2).

In conclusion, on the basis of the phenotypic and genetic features that we have described, the isolates should be classified as representatives of a novel species of the genus Alkalibacterium for which the name Alkalibacterium subtropicum sp. nov. is proposed.

\section{Description of Alkalibacterium subtropicum sp. nov.}

Alkalibacterium subtropicum (sub.tro'pi.cum. L. pref. sub under, below, slightly; L. neut. adj. tropicum tropical; N.L. neut. adj. subtropicum subtropical, referring to the subtropical region where strains were isolated).

Cells are Gram-positive, non-sporulating, non-motile, straight rods measuring $0.5-0.9 \times 3.0-20.0 \mu \mathrm{m}$, occurring singly, in pairs or in short chains and elongated in older cultures (Supplementary Fig. S1). Deep colonies in 2.5\% $\mathrm{NaCl}$ GYPF agar medium are creamy white, opaque and lenticular, with diameters of $1.0-2.0 \mathrm{~mm}$ after 3 days at $30{ }^{\circ} \mathrm{C}$. Surface colonies are round, convex, entire, creamy white and transparent, with diameters of $0.5-1.0 \mathrm{~mm}$ after 3 days at $30{ }^{\circ} \mathrm{C}$. Aerotolerant. Grows evenly throughout a column of semi-solid agar medium. Catalase- and oxidasenegative. Quinones are not detected. Negative for nitrate reduction, gelatin liquefaction and production of ammonia from L-arginine. Slightly halophilic; optimum $\mathrm{NaCl}$ concentration for growth is 1.0-3.0\% (type strain); grows in $0-17.0 \%(\mathrm{w} / \mathrm{v}) \mathrm{NaCl}$. Alkaliphilic; the optimum $\mathrm{pH}$ for growth is 8.0-8.5; grows at $\mathrm{pH} 7.5-9.5$ (type strain). Growth occurs between 15 and $40{ }^{\circ} \mathrm{C}$, with optimum growth at 20 $30{ }^{\circ} \mathrm{C}$. Lactic acid is the major fermentation product from D-glucose; other products are formate, acetate and ethanol in a molar ratio of approximately $2: 1: 1$, without gas formation. Lactate produced is of DL-type. D-Glucose is aerobically metabolized to acetate and lactate (analysed for the type strain). The following carbohydrates and related compounds are fermented: D-ribose, D-xylose, D-glucose, D-fructose, D-mannose, cellobiose, D-lactose, maltose, melibiose, sucrose, trehalose, raffinose, D-mannitol, D-sorbitol (weak for O25-2), D-dulcitol (weak), glycerol (weak), Dsalicin, sodium gluconate, starch and inulin. D-Arabinose and L-rhamnose are not fermented. Variable reactions are observed for L-arabinose, D-galactose, melezitose, adonitol, myo-inositol and methyl $\alpha$-D-glucoside. Growth is inhibited by ampicillin $(10 \mu \mathrm{g})$, chloramphenicol (weakly; $2 \mu \mathrm{g}$ ), kanamycin $(2 \mu \mathrm{g})$ and trimethoprim $(10 \mu \mathrm{g})$. The peptidoglycan is A $4 \beta$, Orn-D-Asp type. Major cellular fatty acids are $\mathrm{C}_{14: 0}, \mathrm{C}_{16: 0}$ and $\mathrm{C}_{16: 1} \omega 9 c$.

The type strain is $\mathrm{O} 24-2^{\mathrm{T}}\left(=\mathrm{DSM} 23664^{\mathrm{T}}=\mathrm{NBRC} 107172^{\mathrm{T}}\right)$, isolated from a decaying marine alga, Galaxaura sp., collected at a foreshore site near the Oujima Islet in Okinawa Prefecture, a subtropical area of Japan. The DNA $\mathrm{G}+\mathrm{C}$ content of strain $\mathrm{O} 24-2^{\mathrm{T}}$ is $43.7 \mathrm{~mol} \%$.

\section{Acknowledgements}

We are grateful to Yasutaka Tokuda for kind help in collecting samples in Okinawa.

\section{References}

Axelsson, L. T. (1993). Lactic acid bacteria: classification and physiology. In Lactic Acid Bacteria, pp. 1-63. Edited by S. Salminen \& A. von Wright. New York: Marcel Dekker.

Carlsson, J. \& Griffith, C. J. (1974). Fermentation products and bacterial yields in glucose-limited and nitrogen-limited cultures of streptococci. Arch Oral Biol 19, 1105-1109.

Fukui, K., Kato, K., Kodama, T., Ohta, H., Shimamoto, T. \& Shimono, T. (1988). Kinetic study of a change in intracellular ATP level associated with aerobic catabolism of ethanol by Streptococcus mutans. J Bacteriol 170, 4589-4593.

Gunsalus, I. C. \& Niven, C. F., Jr (1942). The effect of $\mathrm{pH}$ on the lactic acid fermentation. J Biol Chem 145, 131-136.

Ishikawa, M., Ishizaki, S., Yamamoto, Y. \& Yamasato, K. (2002). Paraliobacillus ryukyuensis gen. nov., sp. nov., a new Gram-positive, slightly halophilic, extremely halotolerant, facultative anaerobe isolated from a decomposing marine alga. J Gen Appl Microbiol 48, 269-279.

Ishikawa, M., Nakajima, K., Yanagi, M., Yamamoto, Y. \& Yamasato, K. (2003). Marinilactibacillus psychrotolerans gen. nov., sp. nov., a halophilic and alkaliphilic marine lactic acid bacterium isolated from marine organisms in temperate and subtropical areas of Japan. Int J Syst Evol Microbiol 53, 711-720.

Ishikawa, M., Nakajima, K., Itamiya, Y., Furukawa, S., Yamamoto, Y. \& Yamasato, K. (2005). Halolactibacillus halophilus gen. nov., sp. nov. and Halolactibacillus miurensis sp. nov., halophilic and alkaliphilic marine lactic acid bacteria constituting a phylogenetic lineage in Bacillus rRNA group 1. Int J Syst Evol Microbiol 55, 2427-2439.

Ishikawa, M., Tanasupawat, S., Nakajima, K., Kanamori, H., Ishizaki, S., Kodama, K., Okamoto-Kainuma, A., Koizumi, Y., Yamamoto, Y. \& Yamasato, K. (2009). Alkalibacterium thalassium sp. nov., Alkalibacterium pelagium sp. nov., Alkalibacterium putridalgicola sp. nov. and Alkalibacterium kapii sp. nov., slightly halophilic and alkaliphilic marine lactic acid bacteria isolated from marine organisms and salted foods collected in Japan and Thailand. Int J Syst Evol Microbiol 59, 1215-1226. 
Jones, B. E., Grant, W. D., Collins, N. C. \& Mwatha, W. E. (1994). Alkaliphiles: diversity and identification. In Bacterial Diversity and Systematics, pp. 195-230. Edited by F. G. Priest, A. RamosCormenzana \& B. J. Tindall. New York: Plenum Press.

Kushner, D. J. (1978). Life in high salt and solute concentrations: halophilic bacteria. In Microbial Life in Extreme Environments, pp. 318-346. Edited by D. J. Kushner. London: Academic Press.

Kushner, D. J. \& Kamekura, M. (1988). Physiology of halophilic eubacteria. In Halophilic Bacteria, vol. I, pp. 109-140. Edited by F. Rodríguez-Valera. Boca Raton, FL: CRC Press.

Liu, J.-R., Tanner, R. S., Schumann, P., Weiss, N., McKenzie, C. A., Janssen, P. H., Seviour, E. M., Lawson, P. A., Allen, T. D. \& Seviour, R. J. (2002). Emended description of the genus Trichococcus, description of Trichococcus collinsii sp. nov., and reclassification of Lactosphaera pasteurii as Trichococcus pasteurii comb. nov. and of Ruminococcus palustris as Trichococcus palustris comb. nov. in the lowG + C gram-positive bacteria. Int J Syst Evol Microbiol 52, 1113-1126.

Nakajima, K., Hirota, K., Nodasaka, Y. \& Yumoto, I. (2005). Alkalibacterium iburiense sp. nov., an obligate alkaliphile that reduces an indigo dye. Int J Syst Evol Microbiol 55, 1525-1530.

Ntougias, S. \& Russell, N. J. (2001). Alkalibacterium olivoapovliticus gen. nov., sp. nov., a new obligately alkaliphilic bacterium isolated from edible-olive wash-waters. Int J Syst Evol Microbiol 51, 1161-1170.
Rhee, S. K. \& Pack, M. Y. (1980). Effect of environmental pH on fermentation balance of Lactobacillus bulgaricus. J Bacteriol 144, 217-221.

Sakamoto, M. \& Komagata, K. (1996). Aerobic growth of and activities of NADH oxidase and NADH peroxidase in lactic acid bacteria. J Ferment Bioeng 82, 210-216.

Tamura, K., Dudley, J., Nei, M. \& Kumar, S. (2007). MEGA4: Molecular Evolutionary Genetics Analysis (MEGA) software version 4.0. Mol Biol Evol 24, 1596-1599.

Toffin, L., Zink, K., Kato, C., Pignet, P., Bidault, A., Bienvenu, N., Birrien, J.-L. \& Prieur, D. (2005). Marinilactibacillus piezotolerans sp. nov., a novel marine lactic acid bacterium isolated from deep subseafloor sediment of the Nankai Trough. Int J Syst Evol Microbiol 55, 345-351.

Yamada, T. \& Carlsson, J. (1975). Regulation of lactate dehydrogenase and change of fermentation products in streptococci. J Bacteriol 124, 55-61.

Yumoto, I., Hirota, K., Nodasaka, Y., Yokota, Y., Hoshino, T. \& Nakajima, K. (2004). Alkalibacterium psychrotolerans sp. nov., a psychrotolerant obligate alkaliphile that reduces an indigo dye. Int $J$ Syst Evol Microbiol 54, 2379-2383.

Yumoto, I., Hirota, K., Nodasaka, Y., Tokiwa, Y. \& Nakajima, K. (2008). Alkalibacterium indicireducens sp. nov., an obligate alkaliphile that reduces indigo dye. Int J Syst Evol Microbiol 58, 901-905. 